\title{
Prostate cancer: emerging pharmacotherapeutic modalities
}

\author{
Pratap Shankar*, Anoop Kumar Verma, Rakesh Kumar Dixit, Amod Kumar Sachan
}

Department of Pharmacology \& Therapeutics, King George's Medical University, Lucknow, India

Received: 3 April 2013

Accepted: 13 April 2013

*Correspondence to:

Dr. Pratap Shankar,

Email: pratap.mbi@gmail.com

(C) 2013 Shankar P et al. This is an open-access article distributed under the terms of the Creative Commons Attribution License, which permits unrestricted use, distribution, and reproduction in any medium, provided the original work is properly cited.

\begin{abstract}
Prostate cancer is the most common cancer in the world due to factors like old age, family history, ethnicity, diet and some elements exposure, with lot of controversies regarding prevention of prostate cancer. Though the exact pathogenesis is not clear, epidemiological evidence supports a relationship between prostate cancer and hormone levels. In this review article we are focusing on the advances in different pharmacotherapeutic modalities i.e. Chemoprevention, Prostate-Specific Antigen, Hormone Therapy, AntiInflammatory Drugs, SERM, Vaccines, Cryotherapy, Watchful Waiting, Radiotherapy and Androgen Deprivation Therapy etc. and new possibilities with strategies to provide maximal benefits while effectively balancing risks for the prostate cancer treatment.
\end{abstract}

Keywords: Prostate Cancer, Pharmacotherapy, Modalities, Chemoprevention

\section{INTRODUCTION}

Prostate cancer is the most common cancer in the world. ${ }^{1}$ Prostate cancer patients have many options within the realms of surgery or different kind of therapies. ${ }^{2}$ In the late $80 \mathrm{~s}$ and early $90 \mathrm{~s}$ great attention was given to screening asymptomatic men by measuring concentration of prostate specific antigen (PSA), which eventually led to a significant increase in the detection of clinically insignificant tumors. ${ }^{3}$ Though the exact pathogenesis is not clear, epidemiological evidence supports a relationship between prostate cancer and serum levels of testosterone. ${ }^{4}$ With some other factors like old age, family history, ethnicity, diet and some elements exposure $^{5}$, Although lot of controversies, strategies are regarding prevention of prostate cancer by early detection with decreasing the mortality. ${ }^{6}$

With the gradual increase in number of prostate cancer patients and with the availability of limited data on optimal treatments, it is necessary to consider the risks and benefits associated with each therapeutic option. ${ }^{7,8}$ The aim of Chemoprevention is to decrease the incidence of the prostate cancer, simultaneously with less adverse events, lowering the cost of treatment and mortality. ${ }^{3}$ The death rate in prostate cancer patients continues to decline, mainly due to early detection and early treatment, with improved salvage therapies. ${ }^{8}$ Curative treatments such as pharmacotherapies are effective for prostate cancer. ${ }^{9-12}$ A range of agents have been suggested to cure/prevent prostate cancer with so many studies in progress. ${ }^{3}$ In this review article we are focusing on the advances in different pharmacotherapeutic modalities and new possibilities with strategies to provide maximal benefits while effectively balancing risks for the prostate cancer treatment.

\section{WE NEED}

With reference not even in prostate cancer only but in all type of cancers, we desired to minimize morbidity and mortality due to prostate cancer. ${ }^{13}$ But the most debatable matter is about to the appropriate therapy of earlystage prostate cancer with several options as surgery, radiation, or expectant management. As per research results till now the only pharmacotherapy as an option for the treatment of advanced prostate cancer. ${ }^{14}$ 


\section{GENERAL APPROACH AGAINST}

By confirming the disease prostate cancer by different diagnostic options such as PSA, DRE and finally by biopsy, assigning with Gleason score, strategies against the prostate cancer are made with reference to the cancer stage, the Gleason score, the presence of symptoms, and the life expectancy of the patient, treatments applied primarily. Treatment is by different treatment options available likely to surgery, radiotherapy, pharmacotherapy etc. ${ }^{15-16}$

\section{CHEMOPREVENTION}

Carcinogenesis induced by genetic and epigenetic changes with multistep molecular process. It can disturb the balance of cell controlling pathways and processes. With reference to literature chemoprevention can be defined as the use of natural or synthetic agents that reverse, inhibit or prevent the development of cancer in cancer-free individuals. $^{3,17}$ This approach used targeting the healthy individuals under developing cancer, using agents with low adverse events. ${ }^{16}$ Large number of agents used for prostate cancer treatment either in primary prevention (prior to diagnosis) or in secondary prevention (recurrence or progression of metastatic disease). ${ }^{18-19}$

\section{PROSTATE-SPECIFIC ANTIGEN}

Widespread use of prostate-specific antigen (PSA) testing has lead to a migration in stage and grade of prostate cancer, with most men presenting with localized disease. ${ }^{15,20}$ Persons with early treatment for prostate cancer may show good results with significant proportion experience disease recurrence. ${ }^{21}$ General consideration regarding the PSA progression is the earliest evidence of persistent or recurrent disease after primary therapy of curative intent..$^{9,11,13,22,23}$ It is still a challenging issue of predicting outcome after PSA progression. ${ }^{24}$ However, variety of prognosis available and not all patients with PSA progression proceed to clinical progression. ${ }^{25}$

\section{HORMONE THERAPY}

With lack of evidences regarding the use of the hormone therapy against prostate cancer, Iversen and colleagues in a randomized controlled trial showed no significant improved survival. ${ }^{26}$ Today, neither the researchers nor the urologists recommend the use of hormone therapies as primary therapy for prostate cancer patients. ${ }^{27,28}$ Beside the above drawback as primary therapy, hormone therapy can be used in combination with other therapies with good results against the prostate cancer for example - in combination with radical prostatectomy ${ }^{29}$; radiation therapy $^{27,28,30}$ and with other treatment modalities for prostate cancer. ${ }^{31-34}$

\section{ANTI-INFLAMMATORY DRUGS}

In prostate cancer prevention non-steroidal antiinflammatory drugs play very important role to prevent the synthesis of endogenous prostaglandins by inhibition of the cyclo-oxygenase (COX) enzyme. ${ }^{35-36}$ Few nonsteroidal anti-inflammatory drugs (NSAIDs) such as aspirin, sulindac and ibuprofen already have been reported to show anti-prostate cancer activity.

\section{SERM}

With great importance in prostate cancer prevention Selective Estrogen - Receptor Modulators (SERM) stimulated by the estrogens in the pathogenesis of prostate cancer through promotion of cell growth. ${ }^{37}$

\section{VACCINES}

With recent development in number of approaches against the prostate cancer prevention as well as treatment, few vaccines are also promising to immunize for the prostate cancer in clinical trials. Trials on vaccines offer great promise for prevention of prostate cancer in the near future. ${ }^{3,38}$ Out of the many treatment approaches against recurrent prostate cancer that no longer responds to hormonal agents, immunotherapy is particularly promising, due to several unique characteristics of both the disease and the treatment. ${ }^{39}$ For better response and treatment the vaccines can also be used in combination with other therapeutic approaches like radiotherapy, chemotherapy, hormonal therapy etc.

\section{CRYOTHERAPY}

Cryotherapy is a relatively new procedure for the treatment of localised prostate cancer. Under anaesthesia, probes are inserted into the prostate tumour that freezes the tissue, thereby killing tumour cells. This procedure is carried out on a day-patient basis and generally patients are allowed home the following day. The main complications associated with cryotherapy include impotence (inability to maintain an erection), incontinence, and tissue sloughing (making urination difficult). Studies report that cryotherapy has potential clinical benefits for many patients with no evidence of cancer postoperatively; however, the quality of the available evidence is poor. ${ }^{40}$

\section{WATCHFUL WAITING}

Watchful waiting is also known as "active surveillance" approach. The main objective of watchful waiting is to use two different approaches for the prostate cancer management. Literature showed it as patient monitoring for symptoms and clinical progression only, and intervening with androgen deprivation therapy upon symptomatic progression. ${ }^{24,41}$ 


\section{RADIOTHERAPY DEPRIVATION THERAPY \\ ANDROGEN}

Many studies have been showed the better clinical diseasefree survival of the patients with advanced prostate cancer using radiotherapy (RT) in combination with androgen deprivation therapy (ADT) versus RT alone. ${ }^{42,43}$ According to one study from the USA, mostly the persons with advance prostate cancer receive external beam RT in combination with long-term ADT. ${ }^{43,44}$

\section{FUTURE MODALITIES}

It is very difficult to state in favors of single future pharmacotherapy out of all pharmacotherapeutic modalities present for the prostate cancer treatment. This is because of greater possibilities of improvement in each individual pharmacotherapeutic modality. So on the basis of all above, we can say, there is a need to improve each and every pharmacotherapeutic modality for the treatment of the prostate cancer. Pharmacotherapy can be a future modality by improvements by research as well as by clinical studies for the treatment of the prostate cancer. $^{45,46}$

\section{CONCLUSION}

With increase and advances in the different therapies mortality from prostate cancer decreases over the past decade. Beside these advances substantially shorten the survival time with a challenge in maintaining the quality of life for survivors. ${ }^{47-50}$ We have described some of the recent advances in the field of prostate cancer treatment, and also tried to highlight few of the many new technologies on behalf of the novel treatment of prostate cancer as pharmacotherapy. With new modalities for treatment of prostate cancer, we are better than ever before able to characterize and treat the prostate cancer and we are learning how to apply these modalities to improved treatment and more effectively. These advances will hopefully contribute to improved treatment with new and novel modality.

\section{ACKNOWLEDGEMENTS}

We are thankful to Indian Council of Medical Research (ICMR), Delhi, India, for support by a grant as Senior Research Fellowship.

Funding: Indian Council of Medical Research (ICMR), Delhi, India

Competing interests: None declared

Ethical approval: Not required

\section{REFERENCE}

1. National Cancer Institute. Cancer Stat Fact Sheets. Available at http://seer.cancer.gov/statfacts/html/ prost.html. Accessed 1 August 2012.
2. Budäus L, Bolla M, Bossi A, Cozzarini C, Crook J, Widmark A, Wiegel T. Functional Outcomes and Complications Following Radiation Therapy for Prostate Cancer: a critical analysis of the literature. Eur Urol 2012;61:112-27.

3. Moorthy HK, Venugopal P. Strategies for prostate cancer prevention: Review of the literature. Indian $\mathrm{J}$ Urol 2008;24:295-302.

4. Ross RK, Bernstein L, Lobo RA, Shimizu H, Stanczyk F, Pike M, et al. 5 Alpha reductase activity and risk of prostate cancer among Japanese and US white and black males. Lancet 1992;339:887-9.

5. Pienta KJ, Esper PS. Risk factors for prostate cancer. Ann Intern Med 1993;118:793-803.

6. Osoba D. Health-related quality of life and cancer clinical trials. Ther Adv Med Oncol 2011;3:57-71.

7. Hou AH, Swanson D, Barqawi AB. Modalities for Imaging of Prostate Cancer. Advances in Urology 2009;818065, doi:10.1155/2009/818065.

8. Uhlman MA, Moul JW, Tang P, Stackhouse DA, Sun L. Risk stratification in the hormonal treatment of patients with prostate cancer. Ther Adv Med Oncol 2009;1:79-94.

9. Amling CL, Blute ML, Bergstralh EJ, Seay TM, Slezak J, Zincke H. Long-term hazard of progression after radical prostatectomy for clinically localized prostate cancer: continued risk of biochemical failure after 5 years. J Urol 2000;164:101-5.

10. Catalona WJ, Smith DS. 5-year tumor recurrence rates after anatomical radical retropubic prostatectomy for prostate cancer. J Urol 1994;152:1837-42.

11. Pound CR, Partin AW, Eisenberger MA, Chan DW, Pearson JD, Walsh PC. Natural history of progression after PSA elevation following radical prostatectomy. JAMA 1999;281:1591-7.

12. Zincke H, Oesterling JE, Blute ML, Bergstralh EJ, Myers RP, Barrett DM. Long-term (15 years) results after radical prostatectomy for clinically localized (Stage T2c or Lower) prostate cancer. J Urol 1994;152:1850-7.

13. Middleton RG, Thompson IM, Austenfield MS, Cooner WH, Correa RJ, Gibbons RP, et al. Prostate Cancer Clinical Guidelines Panel Summary report on the management of clinically localized prostate cancer. The American Urological Association. J Urol 1995;154:2144-8.

14. Fallon B, Williams RD. Current options in the management of clinical stage $\mathrm{C}$ prostatic carcinoma. Urol Clin North Am 1990;17:853-66.

15. Makarov DV, Trock BJ, Humphreys EB, et al. Updated nomogram to predict pathologic stage of prostate cancer given prostate-specific antigen level, clinical stage, and biopsy Gleason score (Partin tables) based on cases from 2000 to 2005. Urology 2007;69:1095-101.

16. Fisher B, Costantino JP, Wickerman DL, Redmond CK, Kavanah M, Cronin WM, et al. Tamoxifen for prevention of breast cancer-report of the national 
surgical adjuvant breast and bowel project P-1 study. J Natl Cancer Inst 1998;90:1371-88.

17. Brawley OW. The potential for prostate cancer chemoprevention. Rev Urol 2002;4:S11-7.

18. Gupta S. Prostate cancer chemoprevention - models, limitations and potential. Int J Oncol 2004;25:113348.

19. Lieberman R. Evolving strategies for prostate cancer chemoprevention trials. World J Urol 2003;21:1-11.

20. Cooperberg MR, Lubeck DP, Mehta SS, et al. Time trends in clinical risk stratification for prostate cancer: implications for outcomes (data from CaPSURE). J Urol 2003;170(6 Pt 2):S21-S25.

21. See W, Iversen P, Wirth M, McLeod D, Garside L, Morris T. Immediate Treatment with Bicalutamide $150 \mathrm{mg}$ as Adjuvant Therapy Significantly Reduces the Risk of PSA Progression in Early Prostate Cancer. Eur Urol 2003;44:512-7.

22. Shipley WU, Thames HD, Sandler HM, Hanks GE, Zietman AL, Perez CA, et al. Radiation therapy for clinically localized prostate cancer: a multiinstitutional pooled analysis. JAMA 1999;281:1598604.

23. Pound CR, Partin AW, Epstein JL, Walsh PC. Prostate-specific antigen after anatomic radical retropubic prostatectomy: patterns of recurrence and cancer control. Urol Clin North Am 1997;24:395406.

24. McLaren DB, McKenzie M, Duncan G, Pickles T. Watchful waiting or watchful progression?: Prostate specific antigen doubling times and clinical behavior in patients with early untreated prostate carcinoma. Cancer 1998;82:342-8.

25. Salagierski M, Schalken JA. PCA3 and TMPRSS2ERG: Promising Biomarkers in Prostate Cancer Diagnosis. Cancers 2010;2:1432-40.

26. Iversen $\mathrm{P}$, Johansson JE, Lodding P, Kylmala T, Lundmo P, Klarskov P, et al. Bicalutamide $150 \mathrm{Mg}$ in addition to standard care for patients with early non-metastatic prostate cancer: Updated results from the scandinavian prostate cancer period group- 6 study after a median follow-up period of 7.1 years. Scand J Urol Nephrol 2006;40:441-52.

27. Heidenreich A, Aus G, Bolla M, Joniau S, Matveev VB, Schmid HP, et al. Eau-guidelines on prostate cancer. Eur Urol 2008;53:68-80.

28. Thompson I, Thrasher JB, Aus G, Burnett AL, Canby-Hagino ED, Cookson MS, et al. Guideline for the management of clinically localized prostate cancer: 2007 update. J Urol 2007;177:2106-31.

29. Boorjian SA, Thompson RH, Siddiqui S, Bagniewski S, Bergstralh EJ, Karnes RJ, et al. Long-term outcome after radical prostatectomy for patients with lymph node positive prostate cancer in the prostate specific antigen era. J Urol 2007;178:864-70.

30. Bolla M. Combination of radiotherapy and hormonotherapy in locally advanced cancers of the prostate. Cancer Radiother 1997;1:439-42.
31. Merrick GS, Butler WM, Wallner KE, Galbreath RW, Allen ZA, Adamovich E, et al. Androgen deprivation therapy does not impact cause-specific or overall survival in high-risk prostate cancer managed with brachytherapy and supplemental external beam. Int $\mathbf{J}$ Radiat Oncol Biol Phys 2007;68:34-40.

32. Machtens S, Baumann R, Hagemann J, Warszawski A, Meyer A, Karstens JH, et al. Long-term results of interstitial brachytherapy (Ldr-Brachytherapy) in the treatment of patients with prostate cancer. World $\mathbf{J}$ Urol 2006;24:289-95.

33. Galalae RM, Martinez A, Mate T, Mitchell C, Edmundson $\mathrm{G}$, Nuernberg $\mathrm{N}$, et al. Long-term outcome by risk factors using conformal high-doserate brachytherapy $(\mathrm{Hdr}-\mathrm{Bt})$ boost with or without neoadjuvant androgen suppression for localized prostate cancer. Int $\mathbf{J}$ Radiat Oncol Biol Phys 2004;58:1048-55.

34. Kumar S, Shelley M, Harrison C, Coles B, Wilt TJ, Mason MD. Neo-adjuvant and adjuvant hormone therapy for localized and locally advanced prostate cancer. Cochrane Database Syst Rev 2006;(4):CD006019.

35. Gupta S, Srivastava M, Ahmad N, Bostwick DG, Mukhtar H. Overexpression of cyclooxygenase-2 in human prostate carcinoma. Prostate 2000;42:73-8.

36. Barqawi A, Thompson IM, Crawford ED. Prostate cancer prevention: an overview of United States Trials. J Urol 2004;171:S5-9.

37. Steiner MS, Raghow S. Antiestrogens and selected estrogen receptor modulators reduce prostate cancer risk. World J Urol 2003;21:31-6.

38. Tarassoff CP, Arlen PM, Gulley JL. Therapeutic vaccines for prostate cancer. Oncologist 2006;11:451-62.

39. Bilusic M, Heery C, Madan RA. Immunotherapy in prostate cancer: Emerging strategies against a formidable foe. Vaccine 2011;29:6485-97.

40. Shelley M, Wilt T, Coles B, Mason M. Cryotherapy for localised prostate cancer. Cochrane Database Syst Rev 2007;(3):CD005010.

41. Moul JW, Anderson J, Penson DF, Klotz LH, Soloway MS, Schulman CC. Early Prostate Cancer: Prevention, Treatment Modalities, and Quality of Life Issues. Eur Urol 2003;44:283-93.

42. Bolla M, Collette L, Blank L, et al. Long-term results with immediate androgen suppression and external irradiation in patients with locally advanced prostate cancer (an EORTC study): a phase III randomized trial. Lancet 2002;360:103-6.

43. Laverdiere J, Gomez JL, Cusan L, et al. Beneficial effect of combination hormonal therapy administered prior and following external beam radiation therapy in localized prostate cancer. Int $\mathbf{J}$ Radiat Oncol Biol Phys 1997;37:247-52.

44. Koupparis AJ, Grummet JP, Hurtado-Coll A, Bell RH, Buchan N, Goldenberg SL, Gleave ME. Radical prostatectomy for high-risk clinically localized prostate cancer: a prospective single 
institution series. Can Urol Assoc J 2011;5:E156E161.

45. Schuster DM, Votaw JR, Nieh PT, et al. Initial experience with the radiotracer anti-1-amino-3-18Ffluorocyclobutane-1-carboxylic acid with PET/CT in prostate carcinoma. J Nucl Med 2007;48:56-63.

46. Apolo AB, Pandit-Taskar N, Morris MJ. Novel tracers and their development for the imaging of metastatic prostate cancer. J Nucl Med 2008;49:2031-41.

47. Choueiri MB, Tu SM, Yu-Lee LY, Lin SH. The central role of osteoblasts in the metastasis of prostate cancer. Cancer Metastasis Rev 2006;25:601-9.
48. Kabeer MA, Lloyd-Davies E, Maskell G, Hohle R, Mathew J. Metastatic prostate cancer masquerading clinically and radiologically as a primary caecal carcinoma. World J Surg Oncol 2007;5:2.

49. Santos-Filho Sebastião David, Missailids Sotiris, da Fonseca Adenilson de Souza, Bernardo-Filho M. Prostate Cancer, Treatment Modalities and Complications: An Evaluation of the Scientific Literature. Braz Arch Biol Technol 2008;51:51-6.

50. Rappuoli R, Aderem A. A 2020 vision for vaccines against HIV, tuberculosis and malaria. Nature 2011;473:463-9.

doi:10.5455/2319-2003.ijbcp20130603

Cite this article as: Shankar P, Verma AK, Dixit RK, Sachan AK. Prostate cancer: emerging pharmacotherapeutic modalities. Int J Basic Clin Pharmacol 2013;2:247-51. 